\title{
De-oiled neem cake as potential bio-additive for low-salt raw skin preservation: a process for salinity reduction in tanneries
}

\author{
N. Vedaraman ${ }^{1} \cdot$ K. V. Sandhya ${ }^{1} \cdot$ V. Brindha ${ }^{2} \cdot$ A. Tamil Selvi ${ }^{2}$ K. C. Velappan ${ }^{1}$.

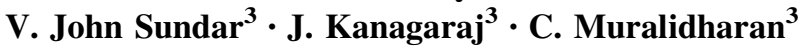

Received: 28 July 2015/Revised: 16 February 2016/Accepted: 12 April 2016/Published online: 27 April 2016

(C) Islamic Azad University (IAU) 2016

\begin{abstract}
Animal skin, a proteinaceous material containing about $60-65 \%$ moisture, is an ideal substrate for the growth of microorganisms, if not preserved properly. Conventionally, large quantities of sodium chloride are used for skin preservation. De-salting and soaking carried out during processing of the skin generates serious environmental constraints. In view of this, low-salt skin preservation with de-oiled neem cake is attempted. To ensure the antimicrobial properties of de-oiled neem cake, aqueous and solvent extracts of the cake were studied against bacteria and fungi which were isolated from raw skin. The antimicrobial assay was performed using the well diffusion method for aqueous, methanol and hexane extract of de-oiled neem cake, which showed maximum zone of clearance for aqueous and methanolic extract against the isolated bacteria and fungi, respectively, present in raw skin. The percentage of inhibition study reveals that the methanolic extract showed $100 \%$ inhibition against many organisms and the water extract against some organisms. The raw skin was cured using de-oiled neem cake with reduced amount of salt and left for a period of 21 days. The skins were checked periodically for microbial growth as per the conventional methods. Finally, the low-salt preserved skins were processed into chrome-tanned leathers and their strength properties were compared with leathers
\end{abstract}

N. Vedaraman

vedaraman.clri@gmail.com

1 Chemical Engineering Division, CSIR-CLRI, Adyar, Chennai 600 020, India

2 CHORD Division, CSIR-CLRI, Adyar, Chennai 600 020, India

3 Tannery Division, CSIR-CLRI, Adyar, Chennai 600 020, India which were preserved by the conventional method. The results suggest that de-oiled neem cake along with minimal salt has adequate curing efficiency on raw skin and if this system is implemented, pollution caused due to sodium chloride would be significantly minimized.

Keywords Antimicrobial activity - Skin curing · Sodium chloride $\cdot$ Leather processing $\cdot$ Environmental pollution

\section{Introduction}

Neem products such as neem oil, de-oiled neem cake, neem based biochemicals such as azadirachtins, neem coated urea are of industrial importance. Neem seed is collected in large quantities, mainly for production of neem oil. The water-washed neem seed kernel cake (Verma et al. 1995), urea-ammoniated neem seed kernel (Anandan et al. 1996) and processed neem kernel (Anandan et al. 1999; Kesava Rao et al. 2003) have been reported as a good food source for goats. De-oiled neem cake is a by-product of the oil industry, and it is relatively low in price and mainly used in agriculture as bio-fertilizer. This is available in large quantities in tropical countries.

Animal skin is a fibrous proteinaceous sheet containing hair, sweat glands, fat and blood vessels, moisture as well as its basic constituent-collagen fibres (Kanagaraj et al. 2005). It is more susceptible for bacterial attack derived from sources like air, water, soil, manure and extraneous filth (Birbir and Ilgaz 1995) leading to disintegration of skin matrix because of their collagenolytic, lipolytic and proteolytic enzymes (Tyagi et al. 2012). So it is important to preserve the skin protein as the leather quality depends upon this protein collagen. The traditional process followed for skin preservation before processing into leather is by 
adding 30-70\% of salt (sodium chloride) based on the skin weight. Even though salt preservation technique is effective, because of its cost competitive and easy availability, it is one of the main sources of the total dissolved solids (TDS) in the effluent discharged from tanneries. This alone contributes $340-450 \mathrm{~kg}$ of salt as TDS per ton of leather processed (Kanagaraj 1999). Chemical-based preservation of skin and hides using sodium sulphate (Vankar and Dwivedi 2009), potassium chloride, boric acid, soda ash, benzalkonium chloride and antibiotics such as aureomycin and terramycin (Kanagaraj and Chandra Babu 2002), bacteriocin (Kanagaraj et al. 2014) were studied to reduce the use of salt for short-term preservation. However, chemical-based preservative is likely to produce secondary pollutants that need to be treated. Hence, they may not be a suitable alternate for this problem. Phyto-based preservation were attempted earlier using the plants such as Weddilia Chininsis, Cassia alatta, Clenodentro phlomider, Salanum trilobotum, Calotropis procera (Sivabalan and Jayanthi 2009), Acalypha indica (Vijayalakshmi et al. 2009) Abutilon glaucum, Agave vera cruz Mill. Alpinia speciosa L., Argyreia speciosa Sweet., Aristolochia bracteolata L., Aristolochia indica L., Asphodelus tenuifolius Cav., Baliospermum montanum, Carissa carandas L., Cassia occidentalis L., Clerodendrum phlomides L., Leptadenia reticulata (Retz.), Murraya paniculata (L.) and Jack, Vitex negundo L. (Vaghasiya and Chanda 2007), Semecarpus anacardium. L.nut extract (Iyappan et al. 2013) for skin preservation, to minimize salinity in tannery effluents.

We reported our earlier studies on use of de-oiled neem cake and Jatropha curas L. cake along with reduced amount of salt as an eco-friendly method for raw skin preservation (Vedaraman et al. 2009) as a proof of concept. In this manuscript, details of microorganisms isolated and identified from putrifacted skin and the antimicrobial properties of de-oiled neem cake extract against the isolated microbes and the effect of preservation of de-oiled neem cake was studied during the first quarter of the year 2015 and were reported.

\section{Materials and methods}

\section{Animal skin}

Freshly flayed goat skins of average weight $1 \mathrm{~kg}$ per piece with an average area of $4 \frac{1}{2} \mathrm{sq}$. $\mathrm{ft}$ were used for the study.

\section{Chemicals}

Sodium chloride (Commercial Grade), de-oiled neem cake from large-scale manufacturer in Chennai, India, was used. Lime, sodium sulphide, ammonium chloride, formic acid, sulphuric acid, sodium bicarbonate, sodium formate and formic acid all are laboratory grade reagents purchased from S. D. Fine chemicals, Chennai, India. Speciality chemicals such as fatliquors and syntans obtained from leading manufacturers, Chennai, India.

\section{Method}

Three freshly flayed goat skins obtained from local slaughterhouse were cut into halves (left and right) along the backbone to avoid skin to skin variation. They were further cut into 2 pieces, i.e., 2 left and corresponding 2 right and considered as experimental and control samples, respectively. Initial experiments were conducted with 10 , $15,20 \%$ salt only to know minimum quantity of salt required for skin preservation. After establishing the minimum amount of salt required, different quantity of deoiled neem cake was used as alternative antimicrobial agent for skin preservation. Further experiments were conducted as per the following procedure: First $10 \%$ of salt was applied on the flesh side of the skin and left in a sliding table for $1 \mathrm{~h}$ to allow the water to ooze out. After $1 \mathrm{~h}$, various quantities of de-oiled neem cake viz., $0,2,5$, $8 \%$ along with $5 \%$ of salt (all percentages based upon the weight of the skin) were applied on the flesh side. For control experiments, $40 \%$ salt was applied on the flesh side. The skins were folded and stored at the ambient temperature of $32-35{ }^{\circ} \mathrm{C}$. The skins were monitored periodically for a period of 21 days for physical changes like smell and hair slip, which are indicators for putrefaction. Skins which were preserved well were only further processed into chrome-tanned leather and finally taken for analysis. The efficacy of the preservation system was assessed based on microbial count. The shrinkage temperature of the tanned leather and physical properties of these leather processed from the skins preserved by the new systems were also determined and compared with the results of conventional salt preserved skins.

\section{Analysis of bioactive compounds present in de-oiled neem cake}

The bioactive compound present in the de-oiled neem cake was analysed using HPLC in a certified testing 
laboratory (M/s Asthagiri Research Foundation, Chennai). The outline of this method is as follows: The methanol extract of de-oiled neem cake was subjected to HPLC analysis using Phenomenex Luna, C18 column $(4.6 \times 250 \mathrm{~mm}$ (5 micron) using UV Detector (Shimadzu SPD 20A) at $215 \mathrm{~nm}$. The mobile phase used was HPLC grade acetonitrile and water $(60: 40)$ at a flow rate of $1.0 \mathrm{ml} / \mathrm{min}$.

\section{Microbiological analyses}

\section{Microorganisms isolation and counts}

Samples from raw and preserved goat skins weighing $1 \mathrm{~g}$ were collected periodically at different time intervals and soaked in $10 \mathrm{ml}$ sterile distilled water. The skin extract was prepared by shaking in a shaker at 30-40 rpm for $30 \mathrm{~min}$. Then, this aliquot measuring $1 \mathrm{ml}$ was serial diluted to $10^{-3}$. A volume of $0.1 \mathrm{ml}$ of the respective dilute solution was taken in sterile petri dish and molten nutrient agar $(3.9 \mathrm{~g} / 100 \mathrm{ml})$ at $40{ }^{\circ} \mathrm{C}$ was poured and shaken gently to get uniform distribution of the bacteria. The plates were incubated at $37{ }^{\circ} \mathrm{C}$ for $24 \mathrm{~h}$. The numbers of colonies on the agar medium were counted as per the standard method (Cruickshank 1965).

\section{Identification of isolated bacteria}

Bacterial isolates were identified by morphological and biochemical analysis according to Bergey's Manual of Systematic Bacteriology (Boone et al. 2001). Morphological and biochemical characterization of different bacterial isolates were carried out by microscopical observations of gram stained cells under oil immersion. And various biochemical studies like indole, methyl red, vogues proskauer, urease, catalase, nitrate reduction etc. were done for the identification of bacteria.

\section{Determination of fungal load}

Samples from raw and preserved goat skins weighing $1 \mathrm{~g}$ were collected periodically at different time intervals and soaked in $10 \mathrm{ml}$ sterile distilled water. The skin extract was prepared by shaking in a shaker at 30-40 rpm for $30 \mathrm{~min}$. Then this aliquot measuring $1 \mathrm{ml}$ was serial diluted to $10^{-3}$. A volume of $0.1 \mathrm{ml}$ of the respective dilute solution was taken in sterile petri plates with $20 \mathrm{ml}$ of molten potato dextrose agar $\left(3.9 \mathrm{~g} / 100 \mathrm{ml}\right.$ distilled water) at $40{ }^{\circ} \mathrm{C}$ and shaken gently to get uniform distribution of the fungi and incubated for $72 \mathrm{~h}$ at room temperature.

\section{Identification of isolated fungi}

The fungi colonies were stained with lactophenol cotton blue and observed under electron microscope, using its hyphae and spore morphology to identify them.

\section{Antibacterial activity}

\section{Extraction of de-oiled neem cake}

De-oiled neem cake weighing $25 \mathrm{~g}$ was suspended in $100 \mathrm{ml}$ of solvent (water, methanol and hexane) and kept in orbital shaker for $48 \mathrm{~h}$ at room temperature. The extract was collected by filtering it with Whatman No. 1 filter paper and concentrated by using rotary evaporator. The extracts thus obtained were taken for further analysis.

Minimal inhibitory concentration (MIC) of de-oiled neem cake against bacteria

MIC was determined by using broth dilution method (Sharief and UmaMaheswara Rao 2011). MIC was analysed for the extracts (water, methanol and hexane extracts) prepared using de-oiled neem cake against the isolated bacterial strains. The different volume taken for study was 1.5, 2.0 and $2.5 \mathrm{ml}$ (extract of $1 \mathrm{mg}$ were dissolved in $10 \mathrm{ml}$ of respective solvents). The results were expressed in percentage of inhibition.

\section{MIC of de-oiled neem cake against fungi}

MIC of de-oiled neem cake extracts (water, methanol and hexane) against fungi isolated from goat skin was studied. The results were expressed in percentage of inhibition.

\section{Leather processing and testing}

\section{Leather processing details}

After the minimum storage period of 21 days, the cured skins were processed as per the process details given in "Appendix".

\section{Determination of hydrothermal stability of chrome- tanned leather}

The thermal stability of collagen is an important property for the assessment of the skin quality, because it indicates 
indirectly any structural destabilization of the skin protein. The thermal stability of the skin is normally assessed by shrinkage temperature. A shrinkage metre was used to determine the shrinkage temperature of the chrome-tanned leathers from preserved skin. The main aim of this component of the study was to understand whether the new curing system had any effect on the destabilization of collagen matrix. The shrinkage temperature of the samples was determined according to the standard method (Standard ISO 2002).

\section{Physical strength of leather}

The preserved skins were converted to crust leather and tested for physical strength properties. After conditioning the crust leather at $20 \pm 2{ }^{\circ} \mathrm{C}$ and $65 \pm 2 \%$ of relative humidity over a period of $48 \mathrm{~h}$, the properties such as tensile strength and tear strength were assessed (Bureau of Indian Standards-5914 1970) in comparison with conventional salted cured leathers.

\section{Pollution load generated in leather processing}

The control and experimental skins were taken for leather processing, the effluent liquor from the soaking operation I and II was mixed together, and a sample from this was quantitatively collected and analysed for TDS, BOD, COD,
TSS and $\mathrm{Cl}^{-}$using standard analytical procedure (Eaton et al. 1995).

\section{Results and discussion}

The goat skins were used for this study. This is mainly because the grain pattern and structure of goat skin allows for identification of even minute changes or variations among experiments. Hence, it is always preferred as substrate for new process development studies. The bacterial colonies were identified by biochemical test as per the standard test methods (Cowan 1985). Table 1 shows that the bacterial colonies isolated from the raw skin were identified using colony morphology, Gram's and biochemical tests, and the bacteria were identified to be Staphylococcus aureus, Pseudomonas aueroginosa, Bacillus cereus, Klebsiella pneumonia, Proteus vulgaris, Salmonella sps., Staphylococcus epidermis and E. coli. Earlier researchers identified both gram-positive and gram-negative bacteria (Ganesh Babu et al. 2009) and different bacterial flora in the raw goat skin (Vijayalakshmi et al. 2009). Research work on antibacterial activity of de-oiled neem cake was tested against Campylobacter jejuni, Carnobacterium sps., Lactobacillus curvvatus, Lactobacillus sakei and Leuconostoc sps. which showed promising results (Del Serrone and Nicoletti 2013). From our study, the colony

Table 1 Microorganisms (bacteria) identified in raw goat skin and their biochemical test results

\begin{tabular}{|c|c|c|c|c|c|c|c|c|}
\hline \multirow[t]{2}{*}{$\begin{array}{l}\text { S. } \\
\text { no. }\end{array}$} & \multirow[t]{2}{*}{ Bacteria } & \multirow[t]{2}{*}{$\begin{array}{l}\text { Gram } \\
\text { staining }\end{array}$} & $\begin{array}{l}\text { Indole } \\
\text { Experimen }\end{array}$ & $\begin{array}{l}\text { MR-VP } \\
\text { onditions }\end{array}$ & VP & Citrate & $\begin{array}{l}\text { Catalyse } \\
\text { activity }\end{array}$ & $\begin{array}{l}\mathrm{H}_{2} \mathrm{~S} \\
\text { production }\end{array}$ \\
\hline & & & $\begin{array}{l}\text { Medium- } \\
\text { Tryptone } \\
\text { broth } \\
\text { Temp. } \\
\quad-37{ }^{\circ} \mathrm{C}\end{array}$ & $\begin{array}{l}\text { Medium-Simmons } \\
\text { citrate medium } \\
\mathrm{pH}-4 \text {, Temp. } \\
\quad-35^{\circ} \mathrm{C}\end{array}$ & $\begin{array}{l}\text { Medium-Voges- } \\
\text { Proskauer broth } \\
\text { Temp. }-37^{\circ} \mathrm{C}\end{array}$ & $\begin{array}{l}\text { Medium- } \\
\text { Christensen's urea } \\
\text { Agar } \\
\text { Temp. }-37{ }^{\circ} \mathrm{C}\end{array}$ & $\begin{array}{l}\text { Temp. } \\
-37^{\circ} \mathrm{C}\end{array}$ & $\begin{array}{l}\text { Temp. } \\
-37{ }^{\circ} \mathrm{C}\end{array}$ \\
\hline 1 & $\begin{array}{l}\text { Staphylococcus } \\
\quad \text { aureus }\end{array}$ & $\begin{array}{c}\mathrm{Gram}^{+\mathrm{ve}}, \\
\text { cocci }\end{array}$ & - & + & \pm & \pm & - & - \\
\hline 2 & $\begin{array}{l}\text { Pseudomonas } \\
\text { aueroginosa }\end{array}$ & $\begin{array}{l}\mathrm{Gram}^{-\mathrm{ve}}, \\
\operatorname{rod}\end{array}$ & - & - & - & + & + & - \\
\hline 3 & Bacillus cereus & $\begin{array}{l}\mathrm{Gram}^{+\mathrm{ve}}, \\
\operatorname{rod}\end{array}$ & - & - & \pm & - & + & - \\
\hline 4 & $\begin{array}{l}\text { Klebsiella } \\
\text { pneumonia }\end{array}$ & $\begin{array}{l}\mathrm{Gram}^{-\mathrm{ve}}, \\
\operatorname{rod}\end{array}$ & - & \pm & \pm & + & + & - \\
\hline 5 & $\begin{array}{l}\text { Proteus } \\
\quad \text { vulgaris }\end{array}$ & $\begin{array}{l}\mathrm{Gram}^{-\mathrm{ve}}, \\
\operatorname{rod}\end{array}$ & + & + & - & \pm & + & + \\
\hline 6 & Salmonella sps. & $\begin{array}{l}\mathrm{Gram}^{-\mathrm{ve}}, \\
\operatorname{rod}\end{array}$ & - & + & - & + & + & + \\
\hline 7 & $\begin{array}{l}\text { Staphylococcus } \\
\text { epidermis }\end{array}$ & $\begin{array}{c}\mathrm{Gram}^{-\mathrm{ve}}, \\
\text { cocci }\end{array}$ & - & - & + & \pm & + & - \\
\hline 8 & E. coli & $\begin{array}{c}\mathrm{Gram}^{-\mathrm{ve}}, \\
\operatorname{rod}\end{array}$ & + & + & - & - & + & - \\
\hline
\end{tabular}

Experiments were repeated thrice for confirmation 
Table 2 Identification of fungi based on colony morphology by lactophenol cotton blue method

\begin{tabular}{llll}
\hline $\begin{array}{l}\text { S. no. } \\
\text { organism }\end{array}$ & Colony morphology (SDA plate) & Stained morphology (lactophenol cotton blue) \\
\hline 1 & $\begin{array}{l}\text { Aspergillus } \\
\text { niger } \\
\text { Rhizopus } \text { sps. }\end{array}$ & $\begin{array}{c}\text { Dense black colour colonies } \\
\text { Colonies }\end{array}$ & Round dense conidia \\
2 & Fuserium sps. & $\begin{array}{c}\text { Cottony dense growth } \\
3\end{array}$ & $\begin{array}{c}\text { Septate broad hyphae and usually unbranched } \\
\text { Cottony aerial mycelium with micro and macro } \\
\text { conidia }\end{array}$ \\
\hline
\end{tabular}

Experiments were repeated thrice for confirmation

Table 3 Minimal inhibitory concentration of de-oiled neem cake extracts

\begin{tabular}{|c|c|c|c|c|c|c|c|c|c|c|}
\hline \multirow[t]{3}{*}{ S. no. } & \multirow[t]{3}{*}{ Bacteria } & \multicolumn{9}{|c|}{ Percentage of inhibition (\%) } \\
\hline & & \multicolumn{3}{|c|}{ Water extract } & \multicolumn{3}{|c|}{ Methanol extract } & \multicolumn{3}{|c|}{ Hexane extract } \\
\hline & & $1.5 \mathrm{ml}$ & $2 \mathrm{ml}$ & $2.5 \mathrm{ml}$ & $1.5 \mathrm{ml}$ & $2 \mathrm{ml}$ & $2.5 \mathrm{ml}$ & $1.5 \mathrm{ml}$ & $2 \mathrm{ml}$ & $2.5 \mathrm{ml}$ \\
\hline 1 & Bacillus cereus & 84.51 & 90.32 & 95.48 & 90.76 & 96.15 & 100 & 69.66 & 82.02 & 89.88 \\
\hline 2 & E. coli & 77.33 & 89.33 & 97.33 & 80.68 & 90.90 & 97.72 & 74.69 & 87.34 & 90.36 \\
\hline 3 & Klebsiella pneumonia & 88.42 & 95.04 & 100 & 81.66 & 95 & 99 & 81.3 & 86.20 & 92.41 \\
\hline 4 & Proteus vulgaris & 88.09 & 97.61 & 100 & 61.33 & 82.6 & 92 & 75.32 & 77.92 & 84.41 \\
\hline 5 & Pseudomonas aueroginosa & 87.36 & 90.52 & 97.89 & 86.15 & 100 & 100 & 62.96 & 66.66 & 81.8 \\
\hline 6 & Salmonella sps. & 100 & 100 & 100 & 100 & 100 & 100 & 63.76 & 73.91 & 89.85 \\
\hline 7 & Staphylococcus aureus & 95.71 & 100 & 100 & 100 & 100 & 100 & 92.42 & 96.21 & 100 \\
\hline 8 & Staphylococcus epidermis & 100 & 100 & 100 & 96.15 & 98.07 & 100 & 60.46 & 65.11 & 79.06 \\
\hline
\end{tabular}

Average value of three experiments

Table 4 Minimal inhibitory concentration of de-oiled neem cake extracts against fungi

\begin{tabular}{|c|c|c|c|c|c|c|c|c|c|c|}
\hline \multirow[t]{3}{*}{ S. no. } & \multirow[t]{3}{*}{ Fungal organism } & \multicolumn{9}{|c|}{ Percentage of inhibition $(\%)$} \\
\hline & & \multicolumn{3}{|c|}{ Water extract } & \multicolumn{3}{|c|}{ Methanol extract } & \multicolumn{3}{|c|}{ Hexane extract } \\
\hline & & $1.5 \mathrm{ml}$ & $2 \mathrm{ml}$ & $2.5 \mathrm{ml}$ & $1.5 \mathrm{ml}$ & $2 \mathrm{ml}$ & $2.5 \mathrm{ml}$ & $1.5 \mathrm{ml}$ & $2 \mathrm{ml}$ & $2.5 \mathrm{ml}$ \\
\hline 1 & Aspergillus niger & 84.51 & 90.32 & 97 & 90.76 & 96.15 & 90 & 69.66 & 82.02 & 89.88 \\
\hline 2 & Rhizopus sps. & 77.33 & 89.33 & 83 & 80.68 & 90.9 & 60 & 74.69 & 87.34 & 90.36 \\
\hline 3. & Fuserium sps. & 12 & 12.5 & 13.2 & 13.9 & 14.4 & 15.1 & 8.9 & 9.5 & 10.1 \\
\hline
\end{tabular}

Average value of three experiments morphology and hyphae morphology by lactophenol cotton blue test of the fungi were identified to be Aspergillus niger, Rhizopus sps., and Fuserium sps. and the results are given in Table 2.

The minimal inhibitory concentration of de-oiled neem cake extracts (water, methanol and hexane extracts) for the isolated bacteria and fungi is given in Tables 3 and 4, respectively. Among three extracts, it was observed that the methanolic extract of de-oiled neem cake had $100 \%$ inhibition against six bacterial species. The methanolic extract of de-oiled neem cake showed better inhibition against the isolated fungi compared with the water and hexane extract. The antifungal properties of neem were reported in earlier studies against Fusarium sps. (Obongoya et al. 2010). Table 5 shows the effect of cake along with salt for skin preservation in comparison with conventional method of salting. Skins preserved with 10 , $15 \%$ salt alone showed hair loosening and generated odour which indicated the commencement of degradation of skin protein. However, skin treated with $15 \%$ salt 
Table 5 De-oiled cake optimization in the preservation of goat skins

\begin{tabular}{lllll}
\hline \% of salt used & & \% of de-oiled neem cake used & \multicolumn{2}{c}{ Raw skin curing characteristics } \\
\cline { 4 - 5 } First instalment & Second instalment & & Hair loosening & Putrefaction odour \\
\hline 10 & 30 & - & Nil & Absent \\
10 & 0 & - & Yes & Present \\
10 & 5 & - & Yes & Present \\
10 & 5 & 2 & Present \\
10 & 5 & 5 & Nil & Absent \\
10 & 5 & 8 & Nil & Absent \\
\hline
\end{tabular}

Experiments were repeated thrice for confirmation

Fig. 1 a ChromatogramHPLC analysis of methanolic extract of de-oiled neem cake. b Chromatogram-HPLC analysis of standard of neem bioactive compounds (a)
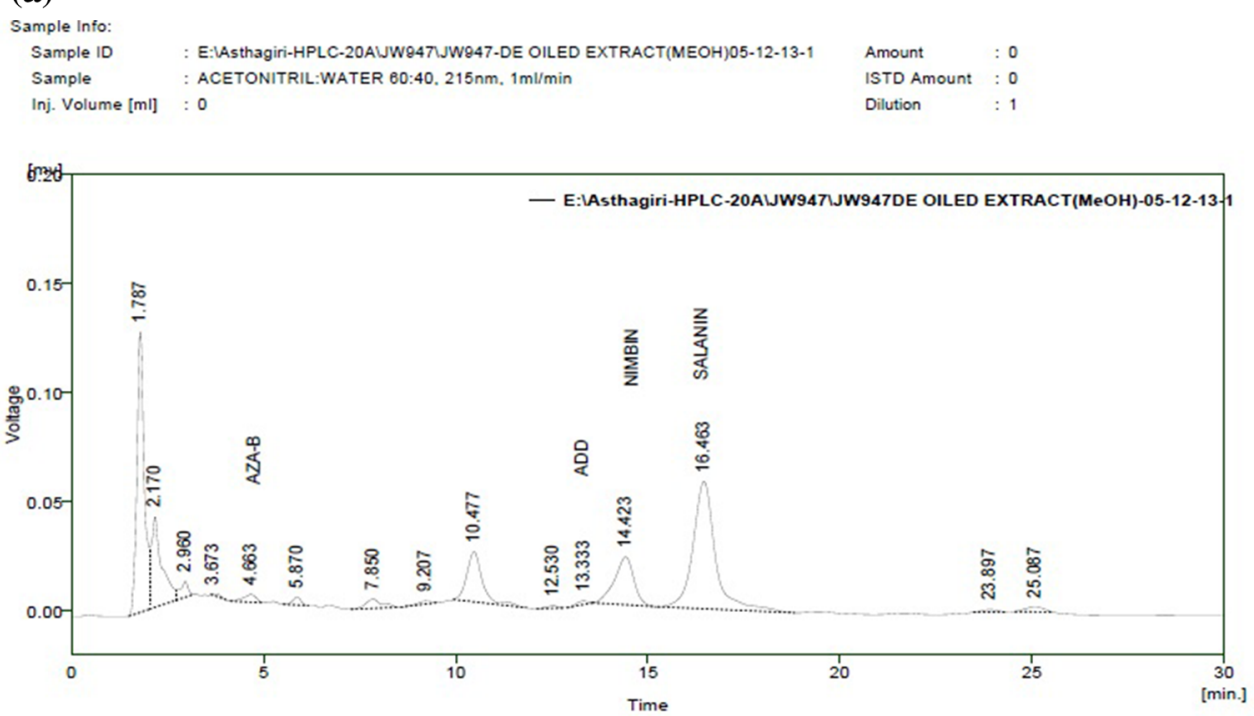

(b)
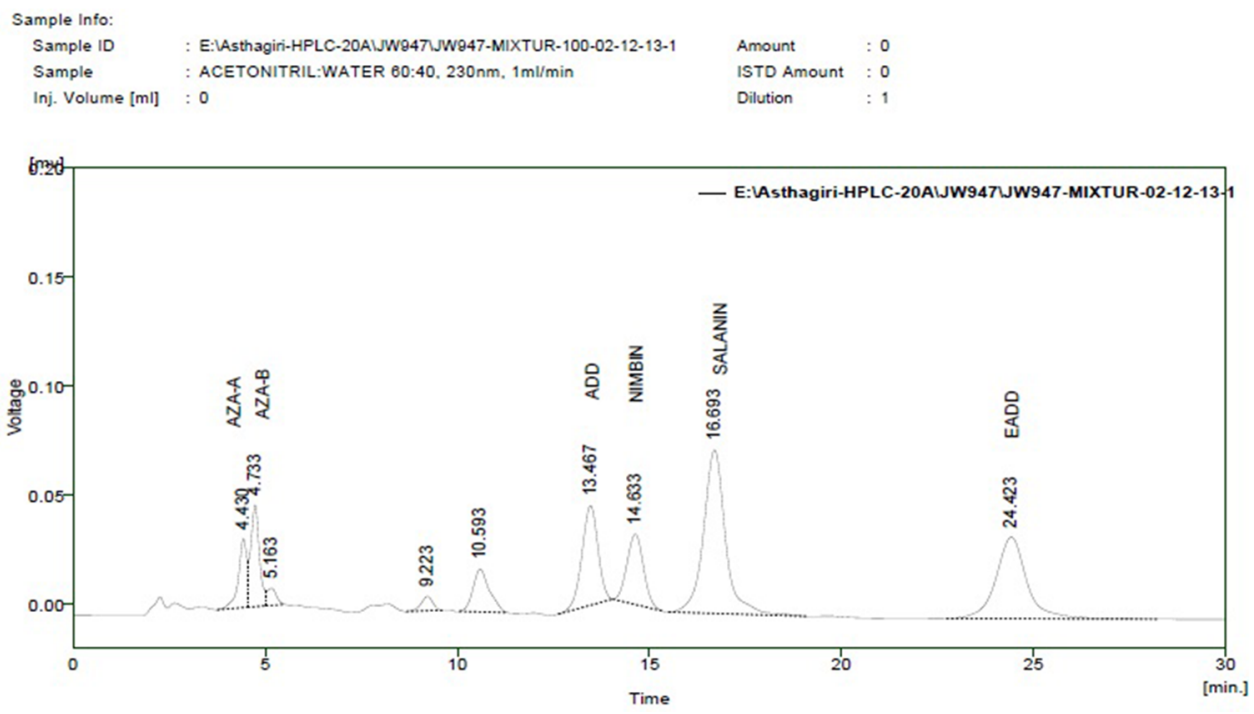
Table 6 Bioactive compounds present in de-oiled neem cake by HPLC

\begin{tabular}{lcl}
\hline Name & Retention time $(\mathrm{min})$ & De-oiled neem cake \\
\hline Azadirachtin B (mg/g) & 4.733 & $0.49 \pm 0.01$ \\
Nimbin $(\mathrm{mg} / \mathrm{g})$ & 14.663 & $4.22 \pm 0.05$ \\
Salannin $(\mathrm{mg} / \mathrm{g})$ & 16.693 & $6.28 \pm 0.05$ \\
\hline
\end{tabular}

Average value of three experiments

along with de-oiled neem cake of 5 and $8 \%$ did not show signs of degradation. Different bioactive compounds present in de-oiled neem cake analysed by HPLC method and their standards are shown in Fig. 1a, b, respectively. Table 6 shows the amount of different bioactive compounds-nimbin, azadirachtin B and salannin in de-oiled neem cake. De-oiled neem cake used in this study contains higher amount of salannin compare to azadirachtin B and nimbin. Neem seed kernel was used as a source from extraction of azadirachtin by HPLC method (Dubhashi et al. 2013). Because of the presence of bitter and toxic triterpenoids, namely nimbin, nimbidin, azadirachtin and salannin, the de-oiled neem cake was not advised as feed stuff (Paul et al. 1996). Studies showed that neem predominantly contains salannin by HPLC method (Del Serrone and Nicoletti 2013). Neem oil cake is given as feed, energy source, protein hydrolysate, biochemical source and used for the production of antibiotics, enzymes and mushroom in industries (Sumitra et al. 2007). Neem cake was found to be a biocontrol agent against nematode (Jothi et al. 2004), and its toxic effect against Aedes albopictus was studied (Nicoletti et al. 2010). Azadirachtin A was extracted from neem seed and studied for its acaricidal activity (Giglioti et al. 2011). All the above studies clearly show neem seed contains different bioactive compounds, and they possess antimicrobial properties.

Tables 7 and 8 show bacterial count and fungal count, respectively, of preserved skin for 1st, 7th and 21st day, with in the storage period of 21 days. The conventional method of salting has slightly more bacterial count compared to low salt with de-oiled cake cured skins. This reveals that phyto-based preservation shows marginally better results when compared with conventional method of preservation. This may be due to antimicrobial properties of salannin, azadirachtin B and nimbin present in de-oiled neem cake. The antibacterial activities of de-oiled neem cake have been proved by other research work also (Del Serrone 2013). The antifungal activity of neem leaves and nimonol has been reported (Mahmoud et al. 2011), thereby proving the antimicrobial activity of de-oiled neem cake used in low-salt skin preservation is due to the presence of nimbin.

Table 7 Bacterial counts on 1st, 7th and 21st day of preserved goat skins

\begin{tabular}{|c|c|c|c|c|c|}
\hline \multicolumn{2}{|l|}{$\%$ of salt used } & \multirow[t]{2}{*}{$\%$ of de-oiled neem cake } & \multicolumn{3}{|c|}{ Bacterial count of skins $(\mathrm{CFU} / \mathrm{ml}) 10^{-3}$} \\
\hline First instalment & Second instalment & & $1 \mathrm{st}$ & 7 th & $21 \mathrm{st}$ \\
\hline 10 & 30 & - & 180 & 87 & 66 \\
\hline 10 & 5 & 2 & 258 & 198 & 108 \\
\hline 10 & 5 & 5 & 178 & 90 & 65 \\
\hline 10 & 5 & 8 & 128 & 74 & 50 \\
\hline
\end{tabular}

Average value of three experiments

Table 8 Fungal count on 1st, 7 th and 21st day of preserved goat skins

\begin{tabular}{llllll}
\hline \% of salt used & & \multirow{2}{*}{ \% of de-oiled neem cake } & \multicolumn{2}{l}{ Fungi count of skins $(\mathrm{CFU} / \mathrm{ml})$} & $10^{-3}$ \\
\cline { 1 - 1 } \cline { 5 - 6 } First instalment & Second instalment & & 1 st & 7 th & 21 st \\
\hline 10 & 30 & - & 10 & 7 & 4 \\
10 & 5 & 2 & 4 & Nill & Nill \\
10 & 5 & 5 & 2 & Nill & Nill \\
10 & 5 & 8 & Nill & Nill & Nill \\
\hline
\end{tabular}

Average value of three experiments 
Table 9 Shrinkage temperature and TDS of preserved goat skins

\begin{tabular}{|c|c|c|c|c|c|c|c|c|}
\hline \multicolumn{2}{|c|}{$\%$ of salt used } & \multirow{2}{*}{$\begin{array}{l}\% \text { of de-oiled neem } \\
\text { cake }\end{array}$} & \multirow{2}{*}{$\begin{array}{l}\text { Shrinkage } \\
\text { temperature }{ }^{\circ} \mathrm{C}\end{array}$} & \multirow{2}{*}{$\begin{array}{l}\text { BOD } \\
(\mathrm{mg} / \mathrm{l})\end{array}$} & \multirow{2}{*}{$\begin{array}{l}\mathrm{COD}(\mathrm{mg} / \\
\text { 1) }\end{array}$} & \multirow[t]{2}{*}{ TDS (g/l) } & \multirow[t]{2}{*}{$\mathrm{Cl}^{-}(\mathrm{mg} / \mathrm{l})$} & \multirow[t]{2}{*}{ TSS (mg/l) } \\
\hline $\begin{array}{l}\text { First } \\
\text { instalment }\end{array}$ & $\begin{array}{l}\text { Second } \\
\text { instalment }\end{array}$ & & & & & & & \\
\hline 10 & 30 & - & $8.7 \pm 1.2$ & $8.7 \pm 1.2$ & $28.7 \pm 0.8$ & $50.01 \pm 0.81$ & $200.4 \pm 0.8$ & $280.0 \pm 9.0$ \\
\hline 10 & 5 & 2 & $7.5 \pm 1.3$ & $7.5 \pm 1.3$ & $25.8 \pm 0.9$ & $13.52 \pm 0.22$ & $98.1 \pm 1.2$ & $102.3 \pm 1.4$ \\
\hline 10 & 5 & 5 & $7.6 \pm 0.9$ & $7.6 \pm 0.9$ & $26.1 \pm 1.1$ & $14.49 \pm 0.19$ & $97.8 \pm 1.5$ & $127.5 \pm 1.5$ \\
\hline 10 & 5 & 8 & $7.5 \pm 0.8$ & $7.5 \pm 0.8$ & $26.3 \pm 1.2$ & $15.02 \pm 0.25$ & $96.9 \pm 1.3$ & $143.1 \pm 1.2$ \\
\hline
\end{tabular}

Average value of three experiments

Table 10 Physical properties of leather

\begin{tabular}{lllll}
\hline $\begin{array}{l}\% \text { of salt used } \\
\begin{array}{l}\text { First } \\
\text { instalment }\end{array}\end{array}$ & $\begin{array}{l}\text { Second } \\
\text { instalment }\end{array}$ & $\begin{array}{l}\text { \% of de-oiled } \\
\text { neem cake used }\end{array}$ & $\begin{array}{l}\text { Tensile } \\
\text { strength } \\
\left.\mathrm{cm}^{2}\right)\end{array}$ & $\begin{array}{l}\text { Tear } \\
\text { strength } \\
(N)\end{array}$ \\
\hline 10 & 30 & - & $205 \pm 5$ & $29 \pm 2$ \\
10 & 5 & 2 & $195 \pm 5$ & $25 \pm 2$ \\
10 & 5 & 5 & $204 \pm 5$ & $28 \pm 2$ \\
10 & 5 & 8 & $204 \pm 5$ & $29 \pm 2$ \\
\hline
\end{tabular}

Average value of three experiments

Hydrothermal stability (Shrinkage temperature) of all the leathers processed from conventional and low salt with de-oiled neem cake cured skins exhibited comparable results. Importantly, a substantial TDS decrease (>70\%), BOD, COD, TSS and $\mathrm{Cl}^{-}$was observed in soak liquor of bioadditive-aided low-salt preserved skin. The results are shown in Table 9. Thus, showing de-oiled neem cake with less salt preservation of the goat skin has not affected the skin matrix and this method of preservation is comparable with the conventional method. Similar bio-based preservations such as Acalypha indica was studied for their curing properties suggested them to an alternative to salt curing for raw hide and skin (Vijayalakshmi et al. 2009). Bacteriocin was also examined to be an effective curing agent for raw hide and skin (Kanagaraj et al. 2014). The leathers obtained from the skins preserved with low amount of salt $(15 \%)$ with de-oiled neem cake $(5 \%)$ possessed similar strength properties as that of the leather obtained from the skins preserved with conventional method (Table 10) which substantiates that the new method of skin preservation has not affected adversely the skin matrix.

\section{Conclusion}

Although the research on law salt preservation of hides and skins has remained topic of intense study, viable technologies have not emerged sofar. The major reasons being lack of cost effectivity, no availability of alternate materials in unorganized and decentralized locations were fresh hides and skins are available in large quantities. The present study obviates both the limitations and may emerge as an agent of change in this domain. Versatility of de-oiled neem cake has been advantageously utilized for minimizing the salinity concerns of tannery effluents. Because of ease of application, the method developed is envisaged to be employed in large scale while ensuring substantial environmental benefits to leather making.

Acknowledgments This research work is funded by CSIR-CLRI under 12th five year plan programme under the research project titled "ZERIS" WP-01.

\section{Appendix}

See Table 11. 


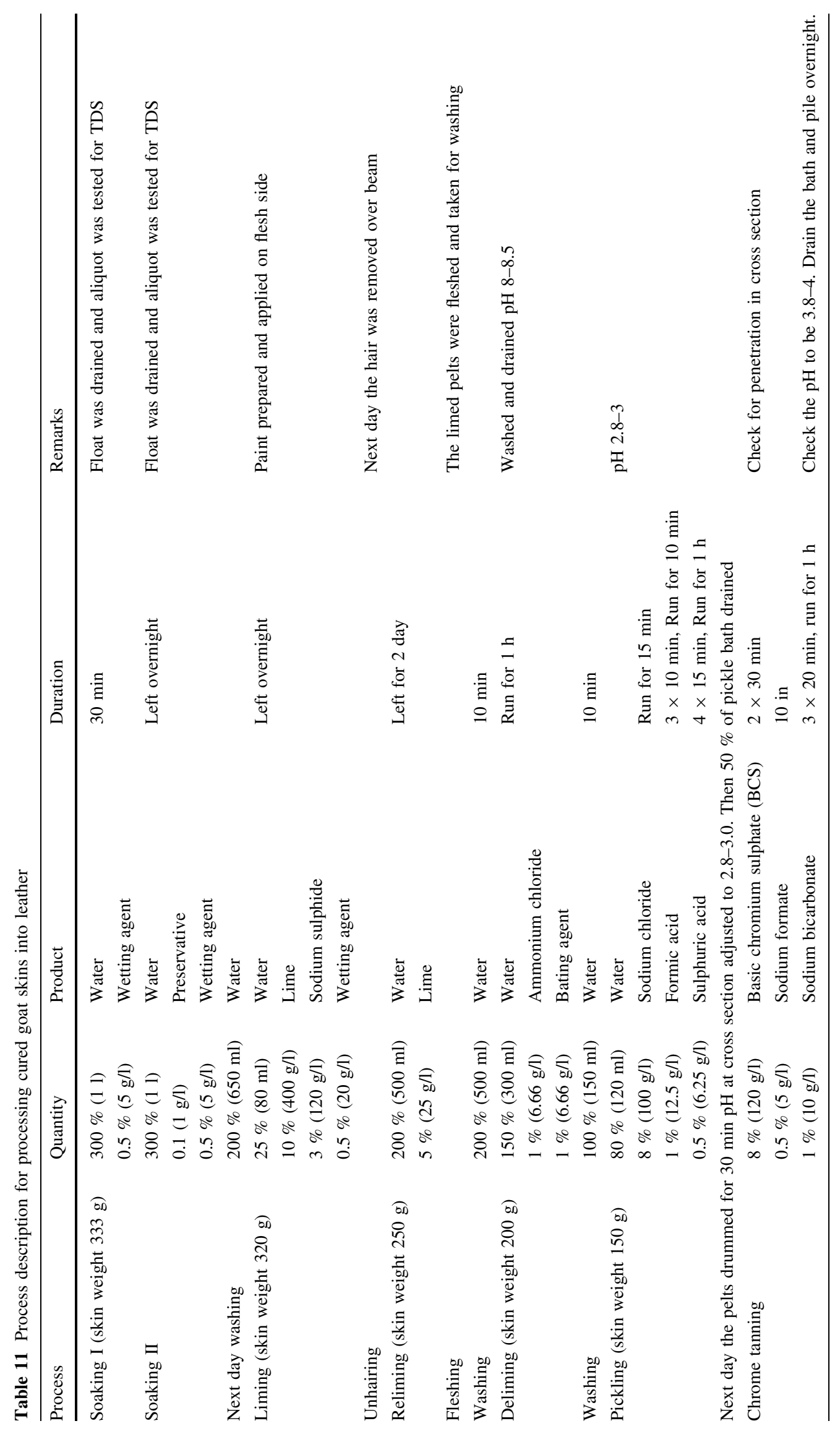




\section{References}

Anandan S, Sastry VRB, Musalia LM, Agrawal DK (1996) Growth rate and nutrient efficiency of growing goat fed urea ammoniated neem seed kernel meal as protein supplement. Small Rumin Res 22:205

Anandan S, Sastry VRB, Katiyar RC, Agrawal DK (1999) Processed neem kernel meal as a substitute for peanut meal protein in growing goat diets. Small Rumin Res 32:125

Birbir M, Ilgaz A (1995) Isolation and identification of bacteria adversely affecting hide and leather quality. J Soc Leather Technol 80:147

Boone DR, Garrity G, Castenholz RW (eds) (2001) Bergey's manual of systematic bacteriology: volume one: the archaea and the deeply branching and phototrophic bacteria, 2nd edn. Springer, New York

Bureau of Indian Standards-5914 (1970) Physical testing of leather, pp 2-70

Cowan ST (1985) Cowan and Steel's manual for identification of medical bacteria, 2nd edn. Cambridge University Press, Cambridge

Cruickshank R (1965) Determination of bacterial count method. Medical Microbiology, 11th edn. E. \& S. Livingstone Ltd, Edinburgh

Del Serrone P, Nicoletti M (2013) Antimicrobial activity of a neem cake extract in a broth model meat system. Int $\mathrm{J}$ Environ Res Public Health 10:3282-3295

Dubhashi S, Pranay V, Satwik M, Singaiah J, Prasad VVLN, Diwan PV (2013) Studies on extraction and HPLC analysis of azadirachtin from kernels of neem seeds. J Adv Pharm Educ Res 3:57-60

Eaton AD, Clesceri LS, Greenberg AE, Franson MHH (1995) Standard methods of the examination of water and wastewater, 19th edn. APHA, Washington

Ganesh Babu T, Nithyanand P, Chandra Babu NK, Pandian SK (2009) Evaluation of cetyltrimethylammonium bromide as a potential short term preservative agent for stripped goat skin. World J Microbiol Biotechnol 25:901

Giglioti R, Forim MR, Oliveira HN, Chagas AC, Ferrezini J, Brito LG, Falcoski TO, Albuquerque LG, Oliveira MC (2011) In vitro acaricidal activity of neem (Azadirachta indica) seed extracts with known azadirachtin concentrations against Rhipicephalus microplus. Vet Parasitol 181:309-315

Iyappan K, Ponrasu T, Sangeethapriya V, Gayathri VS, Suguna L (2013) An eco-friendly method for short term preservation of skins/hides using Semecarpus anacardium nut extract. Environ Sci Pollut Res 20:6324

Jothi G, Babu FS, Ramakrishnan S, Rajendran G (2004) Management of root lesion nematode, $P$. delattreiin cross andra using oil cakes. Bioresour Technol 93:257

Kanagaraj J (1999) Studies on less-salt/salt less curing techniques for the preservation of raw hide/skin. Ph.D. thesis, Anna university

Kanagaraj J, Chandra Babu NK (2002) Alternatives to salt curing techniques-a review. J Sci Ind Res 61:339
Kanagaraj J, Sastry TP, Rose C (2005) Effective preservation of raw goatskins for the reduction of total dissolved solids. J Clean Prod 13:959

Kanagaraj J, Tamil Selvi A, Senthilvelan T, Chandra Babu NK, Chandrasekar B (2014) Evaluation of new bacteriocin as a potential short-term preservative for goat skin. Am J Microbiol Res 2:86

Kesava Rao V, Kowale BN, Verma AK (2003) Effect of feeding water washed neem seed kernal cake on the quality, lipid profile and fatty acid composition of goat meat. Small Rumin Res 47:213

Mahmoud DA, Hassanein NM, Youssef KA, Abou Zeid MA (2011) Antifungal activity of different neem leaf extracts and the nimonol against some important human pathogens. Braz J Microbiol 42:1007-1016

Nicoletti M, Serafini M, Aliboni A, D’ Andrea A, Mariani v (2010) Toxic effects of neem cake extracts on Aedes albopictus larvae. Parasitol Res 107:89

Obongoya BO, Wagai SO, Odhiambo G (2010) Phytotoxic effect of selected crude plant extracts on soil-borne fungi of common bean. Afr Crop Sci J 18:15-22

Paul BN, Haque N, Garg AK (1996) Effect of feeding neem seed kernel cake (Azadirachta indica) on rumen enzyme of buffalo. Ind Vet J 73:720-728

Sharief MN, UmaMaheswara Rao V (2011) Antibacterial activity of stem and root extracts of Avicennia officinalis L. Int J Pharma Appl 2(4):231

Sivabalan V, Jayanthi A (2009) A study to reduce salt usage in preservation of skins and hides with alternate use of plant extract. ARPN J Agric Biol Sci 4(6):43

Standard ISO 3380 (2002) Leather-physical and mechanical testsdetermination of shrinkage temperature up to $100^{\circ} \mathrm{C}$

Sumitra R, Sudheer KS, Christina L, Carlas RS, Ashok P (2007) Oil cakes and their biotechnological applications-a review. Bioresour Technol 98:2000

Tyagi PK, Anwar M, Mukherjee G (2012) Nature and activities of different microorganism on raw hides/skin and their plant based preservation approach. J Indian Leather Technol Assoc 62:319

Vaghasiya Y, Chanda SV (2007) Screening of methanol and acetone extracts of fourteen indian medicinal plants for antimicrobial activity. Turk J Biol 31:243

Vankar PS, Dwivedi AK (2009) Sulphates for skin preservation-a novel approach to reduce tannery effluent salinity hazards. J Hazard Mater 163:207

Vedaraman N, John Sundar V, Rangasamy T, Muralidharan C (2009) Bio-additive aided skin preservation-an approach for salinity reduction. Leather Footwear J 4:251

Verma AK, Sastry VRB, Agrawal DK (1995) Feeding of water washed neem seed kernal cake to growing goats. Small Rumin Res 15:105

Vijayalakshmi K, Judith R, Rajkumar S (2009) Noval plant based formulation for short term preservation of animal skins. J Sci Ind Res 68:699 